\title{
Decentralization: Catalyst for Welfare Service Delivery by Local Government Administration
}

\author{
Dr. Salihu Abdulwaheed (Corresponding author) \\ Faculty Member, School of Government \\ College of Law, Government and International Studies \\ Universiti Utara Malaysia \\ E-mail: adelabusalihu21@gmail.com \\ Dr. Khalil Samihah \\ Dean, Ghazali Shafie Graduate School of Government \\ College of Law, Government and International Studies \\ Universiti Utara Malaysia \\ Email: samihah@uum.edu.my
}

Received: October 21, 2012 Accepted: November 22, 2012 DOI: 10.5296/jpag.v2i4.2665

\begin{abstract}
The paper aims to look at the transferring of authorities, resources and responsibilities from one tier of government (central government) to other tiers of government (state and local governments) in order to deliver efficient and effective welfare service. This transfer serves two basic purposes, namely accountability for resource management and effective welfare service delivery. This can only be possible if the system of co-responsibility between institutions of governance at the central, states and local governments is decentralized effectively. Similarly, the paper intends to critically examine local governments' budget and budgeting system in order to deliver primary education and healthcare service to the public. Therefore, the paper studies the main source of revenue of local governments, and determines how the resources are utilized in providing primary education and healthcare services. The study designs information data sheet to elicit information from at least four local governments in Nigeria. Statutory allocation disbursed to four local governments under consideration for the fiscal year 2008 is considered. Approved annual budget of the local governments is analyzed to determine the differential $(\%)$ in terms of what is budgeted and what is the budget outcomes. The findings reveal average differential of $65.78 \%$ between approved and actual estimates for primary education, and $37.57 \%$ for primary healthcare service in the local government under consideration. This shows that local governments under consideration are not delivering primary education and healthcare services optimally.
\end{abstract}

Keywords: Decentralization, Estimates, and Local Government 


\section{Introduction}

Decentralization is a process of government policy that transfers responsibilities, resources, and/or authority from higher to lower levels of government. Thus, lower levels of government are the recipients of the transferred responsibilities, resources and authority. There are various degrees of decentralization in which few amongst them are fiscal, administrative, institutional, economical, and political decentralization. Decentralized governance, if carefully planned, effectively implemented, and appropriately managed is bound to lead to significant improvement in welfare service delivery through local government administration.

Broadly speaking, decentralization entails the devolution of state assets and power by the central government to local or private decision-making bodies which can range from representative local government, local administrative branches of central government, non-state organization or private individuals and corporations (Ribot, 1999). For Agrawal and Ribot (1999), decentralization is an act in which a central government formally cedes powers to actors and institutions at lower levels in a political-administrative and territorial hierarchy. Such devolving of political power and administrative responsibilities to lower levels of authority involves the creation of realm of decision making in which a variety of lower-level actors can exercise some autonomy of actions and decisions. In the same wise, Ribot (2002) notes that decentralization can be constructively thought of as the strengthening of local institutions in ways that they can be better adapted to play a more representative, responsive and constructive role in everyday lives of the local population. Such strengthening often involves some transfer of financial resources and decision-making power from central government to the local political and administration unit of governance. In essence, decentralization whether it is to local administrative or political actors, entails the creating of a realm of local autonomy defined by inclusive local processes and local authorities empowered with decisions and resources to deliver welfare services in meaningful ways to the local population. Decentralization involves differing dimension of reallocation of political power, administrative authority, service delivery responsibilities, financial resource inclusive of the power to tax among other issues.

Put differently, the concept of decentralization is often conceived in different forms and indeed there is considerable confusion and obfuscation about what constitutes decentralization. As Robertson (1999) notes, decentralization aims at transferring decision-making authority, resources and responsibilities for the delivery of welfare services from the central government to other lower levels of government, agencies, and field offices of central government line agencies. Robertson (2000) posited further that if decentralized governance is carefully planned, effectively implemented and appropriately managed, it can result in significant improvement in the delivery of welfare service to people at local level, the cumulative effect of which can lead to enhanced human development. Decentralization therefore can be conceived as a political process in which the objective of, which is the transfers of responsibilities, resources, and/or political authority from higher to lower levels of government. Decentralization and effective devolution of responsibilities from central to sub-national governments can be an effective way to address service provision, economic 
development and the involvement of citizens and private investors in the provision of public goods noted Saasa, et al (1999).

Ribot (2002) noted that decentralization can be constructively thought of as the strengthening of local institutions to play a more representative, responsive and constructive role in everyday lives of local populations and the countries in which they live. Such strengthening often involves transfers of financial resources and decision-making power from central government to local unit of governance. It is generally believe that for decentralization to be successful it has to encompass the transfer of powers in three sectors. Supporting this position, Manor (1999) and Binswanger (1999) agreed that for decentralization to be successful, it must entail a mixture of three issues namely; democratic, fiscal and administrative decentralization of power and responsibility to local level of authorities. Though these three forms are critical for statecraft, they failed to hold up as analytical categories argued Agrawal and Ribot (1999). According to Agrawal and Ribot (1999), there are three distinct dimensions: actors, powers and accountability, which underlie all acts of decentralization. Rather than being conceived as a simple political tinkering with power and responsibilities, decentralization in reality entails complex policy issue and there are various dimensions to it which includes; fiscal, administrative, institutional, economical, and political decentralization. Without mincing words, decentralization is best practiced by local government administration in order to deliver efficient and effective welfare service to the public.

A local government is an institution whose operations address the needs and aspiration of the citizenry and also extends the administrative and political control to the community (Wanjohi, 2003). This can easily be attained through democratic decentralization. Ola (1984) posited that local government administration exists to provide essential services, and serve as a vehicle for local development. Adamolekun (1983) lends credence to the position of Ola (1984) by postulating that the goal of local government administration is to provide efficient welfare services in their local jurisdiction. Many researchers including Mass (1959), Oladosun (1981), Adamolekun (1983), Ola (1984), Aghayere (1987), Okeem (1989) and Lawal (2000) in the recent past have discussed extensively on service delivery in the rural areas.

Local government administration cannot, therefore be ideal from the financial view lens if it collects its revenue in a slip-shod manner and devotes a large percentage of it to the maintenance of a top- heavy administrative set-up, with a relatively small proportion of the revenue left for the provision of essential services which are of direct benefits to the local inhabitants (Orewa et al., 1983). Cognizant of this reason, there are multifarious factors militating against the delivery of welfare services by local government such as insufficient fund/resources, bad governance, leadership quality, corruption, managerial accountability, political instability, government policy from other tiers of government, and embezzlement, and mismanagement of funds. Out of these multifarious hindrances, this study is interested on the use of decentralization as a catalyst of welfare service delivery by local government administration.

The delivery of primary education and healthcare service continues to be a major challenge to 
responsible and responsive local government, most especially in the developing countries. In view of its importance, a major focus of reforms in many developing countries has revolved around the redesigning of structures, systems, and processes by which primary education and healthcare service delivery at the local government level can be improved upon. Some of the areas and issues that local government reforms in developing countries have addressed includes; decentralization of resources and responsibilities, reforms among the tiers of government, reforms in pattern of operations of government ministries, departments, agencies; reforms dealing with commercialization and privatization of service provision, contracting out of public goods, and the use of range of public private partnerships initiatives in service provisions with the intended objectives of enhancing the capacity for service provisions and improving efficiency in delivery (Draper, 2004).

Robinson (2007) asserted that most of the reforms being embarked upon for the realization of welfare service delivery have failed the people, especially the poor. Part of the reason canvassed by him is that public spending by sub-national units of government (state-regional-provincial and local government) on welfare services most often failed to reach the public. It is therefore suggested that there should be decentralization of power, responsibilities and revenue to local government based on the assumption that local governments being the closest tier of government to the people will be in better position to identify peoples' needs and be more responsive to ensure that welfare services such as primary education and healthcare is provided to the public (Smoke, 1999). This believe informed the strong emphasis on the call for and implementation of reforms directed at enhancing the decentralization of political power and authority, administrative responsibilities and fiscal capacity to sub-national units of government across many developing countries.

Given that the delivery of welfare services, especially primary education and healthcare as the cornerstone of local governments, then it is safe to infer that efficient and effective service delivery is the core objective for investing local administrative authority with power, responsibility and resources (Salihu, 2011). However, this objective only becomes possible if the system of co-responsibility between institutions of governance at the central, states and local government according to the principle of subsidiary could be effectively established. This brings to the fore the issue of decentralization among the three tiers of government.

\section{Literature Review}

According to Manor (1999), all countries of the world are experimenting with decentralization to address different kinds of problems relating to economic, social and political issues in governance. Majorly, there are two aspects of decentralization, namely fiscal and administrative decentralization. Fiscal decentralization refers to the set of policies designed to increase the revenues or fiscal autonomy of sub-national governments. Put differently, Boschmann (2009) conceived of fiscal decentralization as relating to the transfer of functions or authority from central levels of government to local institutions regarding local decision-making on the allocation of financial resources (financial discretionary powers) and the powers to levy local taxes. Fiscal decentralization has four major components: allocation of expenditure responsibilities by central and local governments; assignment of 
taxes by government tiers; design of an intergovernmental grant system; and the budgeting and monitoring of fiscal flows between different government tiers (Elhiraika, 2007). Numerous studies have sought to measure fiscal decentralization in relation to the degree of official accountability, control of corruption and/or quality of governance (Bahl \& Linn, 1994; Bird \& Vailancourt, 1995; Carrello, 1997; Manor \& Richard, 1998; Bardhan, 2002; Hee-Soun \& Richard, 2007). Unlike this earlier stated and other related conception of fiscal decentralization that merges revenues and expenditures together, there are other scholars who separate the concept of fiscal decentralization of revenue from expenditure. Revenue is seen as fiscal decentralization, while expenditure is seen as administrative decentralization.

Wibbels (2004) opined that the transfer of revenues and/or the authority to raise revenue through the granting of degree of taxing power as fiscal decentralization, while the authority to determine expenditures related issues as administrative decentralization. This analytical separation makes it easier to evaluate the consequences of decentralization processes where the transfer of revenues and expenditures growth path did not correlate. In one of his studies, Manor (1999) highlighted the imbalances in the transfer of fiscal revenue and expenditure responsibilities to sub-national unit of government through fiscal empirical statistical data of what is actually transfered to the sub national governments of the world in 1980. The sub national governments around the world collected an average of $15 \%$ of the revenues of the national governments, and spent $20 \%$ as expenditures. By the year 2000 , the figure rose to $19 \%$ and $25 \%$ respectively. In this context, the disbursement of revenue is viewed as fiscal decentralization, while the delivery of welfare and social services is viewed as administrative decentralization.

By considering different theories and methodological approaches, literatures on decentralization divided the process into components. Policy-oriented theorists undertook studies on administrative reforms aspect of decentralization inclusive of the transfer of responsibilities such as provision of education and healthcare services to the lower levels of government (Di Gropell \& Cominetti, 1998). Administrative decentralization may have positive or negative impact on the autonomy of local government executives. If administrative decentralization improves local bureaucracies, fosters training of local officials, and facilitate learning through the practice of delivering new responsibilities, it will surely increase organizational capacities of local government administration. Contrarily, if administrative decentralization takes place without adequate transfer of funds, it may decrease the autonomy of local government officials; because they are largely depend on national fiscal transfers for the delivery of welfare services. Thus, evolving a modality for the transfer of needed fund become a cardinal issue on which the success of any forms of decentralization hinges (Escobar-Lemmon, 2001).

Evidence abounds that if countries decentralize more expenditure responsibilities than revenue resources, welfare services may fail at the local governments' level. Then, local governments will demand for either more transfers from the central government or loans from commercial banks or both to argument its revenue shortfall in relations to responsibilities. The experience of the Russian federation is one of the most analyzed instances of such revenue-responsibilities disparity (Wallich, 1994). It is equally argued that 
if more revenue resources are decentralized than expenditure responsibilities, local government internally generated revenue (IGR) mobilization will decline, which may eventually lead to macroeconomic imbalances. Lastly, if both sides of the budget are decentralized in a balance fashion, local government officials may not have adequate administrative or technical capacity to carry out the function of welfare service delivery in a satisfactory fashion. These problems are frequently associated with developing countries, where local governments are charged with the delivery of important welfare services (Bird, 1994a). The solution to these problems is to ensure that decentralization is undertaken in such a fashion that will increase accountability and transparency in governance process.

Given some of the challenges of revenue transfer earlier noted, most developed countries are reshaping their intergovernmental fiscal structure in tune with the realities of the "post-welfare state" (Bennett, 1990; Wildasin, 1997a). This is in line with the position of Bird, Ebel and Wallich (1995) when they argued that most of the developed countries are setting up new systems of local and intergovernmental finance to meet changing realities of governance. In the same wise, developing and emerging countries are carrying out one form of reforms or the other on decentralization in order to navigate the crisis of ineffectiveness and inefficiencies in governance process in relation to welfare service delivery.

As a result comprehensive study on decentralization, there are two schools of thought in the critical review of decentralization. Some researchers argued for decentralization on grounds of cost efficiency, improved accountability and increased resource mobilization. Other researchers argued that none of these virtues can be achieved, especially if citizens' preferences are not captured in the budget and the institutional capacity of the sub national governments is weak. From the budget and institutional perspective, Prud'homme (1995) opined in the context of budget disparity and institutional weakness, decentralization might likely result in increased costs, lessened efficiency in welfare service delivery, greater inequity and macroeconomic instability.

It is easier to evaluate either side of the two schools of thought. With respect to efficiency, the standard economic view is that the existence of different tax-spending packages in different jurisdictions, coupled with individual mobility, is sufficient to ensure that there will be efficiency-producing interjurisdictional competition in service provision (Tiebout, 1956). Similarly, empirical evidence from a number of countries studies supports the proposition that locally controlled services are likely to be provided at lower costs than centrally provided ones (Campbell, Peterson and Brakarz, 1991).

Researchers have tried to develop a wealth of theories to explain the causes and effects of transferring authority and resources from central to sub national governments. Few amongst the theories used by researchers to study decentralization include optimistic theories, public choice theories and normative theories. Optimistic theories started with Montesquien and continue through modern welfare researchers, who stressed the advantages of accountability in more decentralized governance structures. Public choice theories emphasize that mobility in a decentralized, multijurisdictional context can facilitate better matching of citizen preferences and government policy through sorting and this can eventually lead to smaller, 
more efficient, less corrupt government and faster growth and development.

Within the scope of this paper, fiscal policy refers to revenue-expenditure relations in the economic parlance. Thus, it refers to government spending practice to influence efficient welfare service delivery aimed at avoiding fiscal crisis through a balanced budget and budgeting system by any tier of government. According to Akindele et al. (2002), the proper control of public finance is efficiently done through proper budgeting, which must be implemented by policy makers by formulating appropriate policies leading to efficient welfare service delivery. The fact remains obvious that local government administration is a quasi- government that is under state government. Therefore, the fiscal decentralization by state government most often is not usually disbursed to local governments as a result of quasi-nature of local government administration. Under the fiscal policy of any organization, being it private, public and/or quasi-public, there must be fiscal autonomy and fiscal discipline in order to allow the organization to deliver the target aims and objectives of the organization. The issue of finance and effective management of the said finance are paramount in any organization, if the objective is to be delivered. Therefore, aggregate fiscal discipline needs to be ensured in the local government administration.

The bane of the third tier of government is imbalance between responsibilities assigned local government and revenue available to local government. The third tier of government often complains that the available resources cannot match with responsibilities assigned to them, especially with regards to primary education and primary health care service delivery (Anyanwu, 1999).

\section{Design/Methodology/Approach}

This study is premised on qualitative analysis, where Public Expenditure Tracking Survey (PETS) is adopted. Thus, the survey examines the estimates of budget and budget outcomes, which is the concern of the study.

Therefore, information data sheet is used to collect information from the archive of four local governments in Nigeria. Also, the statutory allocation for the fiscal year 2008 of the four local governments under review is obtained from the official website of the Federal Ministry of Finance, Nigeria. Lastly, the estimates of the local governments under review for the fiscal year 2008 are obtained through the designed information data sheet.

Information elicited from the archives of the four local governments is therefore analyzed. Percentage discrepancies are calculated to determine the level of efficient delivery of welfare service (primary education and healthcare service) by local governments under consideration. The discrepancies are obtained by comparing the approved estimates (budgets) with what is expended (budget outcomes) on the delivery of primary education and healthcare service by local governments.

\section{Analysis}

The statutory allocation for the local governments under consideration for 2008 fiscal year is obtained and analyzed. The mode of disbursement shows that funds are being disbursed 
monthly and promptly to local governments. From the pattern of disbursement, evidence abounds that local government administration is solvent on the issue of funding, and should be capable of delivering efficient welfare services to the public. Besides, the paper analyzed the approved annual budget of the local governments under review with respect to primary education and healthcare services. The differential in terms of percentages is therefore obtained, and analyzed to determine the level of delivery by local government administration.

The analysis is hereby given below as:

Table1: Statutory Allocation Disbursed to Four (4) LGs for the Fiscal Year 2008

\begin{tabular}{|l|l|l|l|l|}
\hline Months & LG1 & LG2 & LG3 & LG4 \\
\hline 1 & $53,864,415.65$ & $69,415,267.04$ & $62,533,792.53$ & $104,643,335.80$ \\
\hline 2 & $94,173,225.22$ & $122,231,253.83$ & $109,688,160.44$ & $181,757,075.90$ \\
\hline 3 & $83,288,947.33$ & $93,778,479.26$ & $98,690,688.76$ & $123,025,808.48$ \\
\hline 4 & $133,121,971.00$ & $149,262,818.00$ & $160,689,847.42$ & $195,463,686.00$ \\
\hline 5 & $81,436,356.76$ & $91,515,036.06$ & $97,426,536.70$ & $120,191,918.84$ \\
\hline 6 & $370,513,000.83$ & $415,503,647.54$ & $445,286,733.68$ & $541,990,679.24$ \\
\hline 7 & $82,099,761.55$ & $92,268,256.37$ & $98,202,159.57$ & $121,214,293.10$ \\
\hline 8 & $83,567,372.47$ & $93,927,650.78$ & $99,862,583.40$ & $123,469,440.62$ \\
\hline 9 & $80,530,478.43$ & $90,458,012.53$ & $96,379,970.46$ & $118,660,318.03$ \\
\hline 10 & $82,130,722.90$ & $92,273,621.61$ & $98,205,142.68$ & $121,141,155.43$ \\
\hline 11 & $82,945,178.02$ & $93,201,999.86$ & $99,141,741.27$ & $122,420,004.49$ \\
\hline 12 & $81,135,559.88$ & $91,142,694.47$ & $97,051,139.30$ & $119,598,532.18$ \\
\hline TOTAL & $\mathbf{1 , 3 0 8 , 8 0 6 , 9 9 0 . 0 0}$ & $\mathbf{1 , 4 9 4 , 9 7 8 , 7 3 7 . 0 0}$ & $\mathbf{1 , 5 6 3 , 1 5 8 , 4 9 6 . 0 0}$ & $\mathbf{1 , 9 9 3 , 5 7 6 , 2 4 8 . 0 0}$ \\
\hline
\end{tabular}

Source: $\quad$ Federal Ministry of Finance, Nigeria

Note: USD 1.00 is equivalent to \#157.06 (\# represents Nigerian Currency) 


\section{Macrothink}

Journal of Public Administration and Governance

ISSN 2161-7104

2012, Vol. 2, No. 4

Table 2: Differential (\%) for Primary Education in the Annual Budget of the Four (4) LGs

\begin{tabular}{|c|c|c|c|c|c|}
\hline Sub-Heads & $\begin{array}{l}\text { Details of } \\
\text { Expenditure }\end{array}$ & $\begin{array}{l}\text { Differential (\%) } \\
\text { LG1 }\end{array}$ & $\begin{array}{l}\text { Differential } \\
(\%) \\
\text { LG2 }\end{array}$ & $\begin{array}{l}\text { Differential } \\
(\%) \\
\text { LG3 }\end{array}$ & $\begin{array}{l}\text { Differential } \\
(\%) \\
\text { LG4 }\end{array}$ \\
\hline 1 & $\begin{array}{l}\text { Classroom } \\
\text { Construction }\end{array}$ & $66.69 \%$ & $65.18 \%$ & $78.64 \%$ & $57.11 \%$ \\
\hline 2 & $\begin{array}{l}\text { Classroom } \\
\text { Rehabilitation }\end{array}$ & $78.17 \%$ & $48.70 \%$ & $90.02 \%$ & $44.46 \%$ \\
\hline 3 & $\begin{array}{l}\text { Libraries } \\
\text { Construction }\end{array}$ & $37.31 \%$ & $37.85 \%$ & $88.38 \%$ & $51.83 \%$ \\
\hline 4 & $\begin{array}{l}\text { Purchase of } \\
\text { Furniture }\end{array}$ & $49.25 \%$ & $34.87 \%$ & $91.59 \%$ & $75.50 \%$ \\
\hline 5 & $\begin{array}{l}\text { Purchase of } \\
\text { Textbooks }\end{array}$ & $78.00 \%$ & $53.74 \%$ & $97.50 \%$ & $53.16 \%$ \\
\hline 6 & $\begin{array}{l}\text { Bursary } \\
\text { Awards }\end{array}$ & $45.00 \%$ & $2.99 \%$ & $92.25 \%$ & $65.00 \%$ \\
\hline 7 & $\begin{array}{l}\text { Vocational } \\
\text { Training }\end{array}$ & $50.00 \%$ & $56.18 \%$ & $100.00 \%$ & $45.98 \%$ \\
\hline 8 & $\begin{array}{l}\text { Counterpart } \\
\text { Funding }\end{array}$ & $100.00 \%$ & $97.50 \%$ & $99.50 \%$ & $70.00 \%$ \\
\hline & Total Heads & $65.46 \%$ & $56.10 \%$ & $83.45 \%$ & $58.11 \%$ \\
\hline
\end{tabular}


Table 3: Differential (\%) for Primary Healthcare in the Annual Budget of the Four (4) LGs

\begin{tabular}{|c|c|c|c|c|c|}
\hline Sub-Heads & Details of Expenditure & $\begin{array}{l}\text { Differential } \\
(\%) \\
\text { LG1 }\end{array}$ & $\begin{array}{l}\text { Differential } \\
(\%) \\
\text { LG2 }\end{array}$ & $\begin{array}{l}\text { Differential } \\
(\%) \\
\text { LG3 }\end{array}$ & $\begin{array}{l}\text { Differential } \\
(\%) \\
\text { LG4 }\end{array}$ \\
\hline 1 & $\begin{array}{l}\text { Health post } \\
\text { Rehabilitation }\end{array}$ & $65.25 \%$ & $57.02 \%$ & $97.01 \%$ & $3.35 \%$ \\
\hline 2 & $\begin{array}{l}\text { Purchase \& Maint. of } \\
\text { Vehicles }\end{array}$ & $2.23 \%$ & $27.26 \%$ & $51.82 \%$ & $2.19 \%$ \\
\hline 3 & Abattoir Construction & $53.10 \%$ & $37.57 \%$ & $100.00 \%$ & $24.34 \%$ \\
\hline 4 & $\begin{array}{l}\text { Immunization } \\
\text { Programs }\end{array}$ & $13.05 \%$ & $10.98 \%$ & $23.05 \%$ & $5.10 \%$ \\
\hline 5 & Medical Equipment & $19.20 \%$ & $28.57 \%$ & - & $18.11 \%$ \\
\hline 6 & $\begin{array}{l}\text { Campaign against } \\
\text { AIDS }\end{array}$ & $4.33 \%$ & $22.09 \%$ & $86.59 \%$ & $9.86 \%$ \\
\hline 7 & $\begin{array}{l}\text { Environmental } \\
\text { Services }\end{array}$ & $25.88 \%$ & $31.62 \%$ & $51.45 \%$ & $6.86 \%$ \\
\hline 8 & $\begin{array}{l}\text { Water to Health } \\
\text { Institutions }\end{array}$ & - & $21.85 \%$ & $100.00 \%$ & $17.72 \%$ \\
\hline 9 & Toilets Construction & $7.48 \%$ & $17.74 \%$ & $100.00 \%$ & $4.89 \%$ \\
\hline 10 & Provision of Drugs & $26.31 \%$ & $59.15 \%$ & $100.00 \%$ & $37.26 \%$ \\
\hline 11 & $\begin{array}{l}\text { General } \quad \text { Health } \\
\text { Programs }\end{array}$ & $22.72 \%$ & $1.29 \%$ & $83.91 \%$ & $60.58 \%$ \\
\hline & Total Heads & $30.22 \%$ & $35.07 \%$ & $68.20 \%$ & $16.77 \%$ \\
\hline
\end{tabular}

\section{Discussion}

From Table 1 above, evidence abounds that statutory allocation is being disbursed regularly and promptly by central government in Nigeria. This shows that local governments in Nigeria are financially buoyant to deliver primary education and healthcare service to the public in their various local jurisdictions. The monthly disbursement follows same sequence in the 
disbursement of statutory allocation in all the 774 local governments in Nigeria.

From Table 2 above, it is clearly shown that estimate approved for each sub-head is not being spent at the end of the fiscal year in the local government under review. Evidence from Table 2 shows that over $50 \%$ of what is often approved for primary education items is not spent on those items. By the differential, the delivery of primary education by local government administration is not optimally efficient. Averagely, $65.78 \%$ of the budget outcomes on primary education are not actualized by local government administration under consideration.

For primary healthcare service, Table 3 evidently shows that the service is not being optimally delivered. The approved annual budget of the local government under review shows that there exist discrepancies between what is budgeted and budget outcomes. On the average, $37.57 \%$ of what suppose to be budget outcomes are not spent on primary healthcare items at the end of 2008 fiscal year.

It therefore becomes imperative to ensure aggregate fiscal discipline in the use of decentralization as a catalyst to deliver essential services to the public by local government administration.

\section{Research implication/recommendation}

The implication of this study is to show the modality by which government generates and disburses its revenues/resources among tiers of government on one hand, and how these revenues/resources are spent based on designed financial plan (budget) for every fiscal year according to the citizenry's needs on the other. Similarly, the study examines the workability of budgetary votes on the delivery of primary education and healthcare service, using local government administration as a case study.

The study therefore recommends that theories, concepts and nomenclatures of public financial management should be the watch-dog of local government administration, if effective and efficient social and welfare services are to be delivered. Lastly, there should be a strong correlation between good fiscal policy via budgeting system and government activities in the area of service delivery to the public.

\section{Conclusion}

It is observed in the study that governments' enormous public resources are not translating to efficient primary education and healthcare service to the public by local government administration. Local government administration in Nigeria receives transfers from central and state governments to enable them deliver the preferential needs and aspirations of the citizens in their jurisdiction. This objective can only be realized through aggregate fiscal discipline in the cause of using the concept of decentralization among the three tiers of government. It is equally observed that budget outcomes on the delivery of primary education and healthcare service by local government administration is not optimally realized, there are other researchers such as (Lawal, 2000; Olowu, 2001; Ajayi, 2002; Akindele, 2004; Awotokun, 2005) who lend credence to the findings of this study by saying that local governments most often do not spend what is approved for service delivery in the budget, 
instead they prefer to divert resources to other programs in the name of virement.

The bane of not delivering services by local government administration can be viewed from fiscal policy indiscipline. So, the policy/decision-makers should ensure good fiscal planning in order to deliver efficient and effective welfare services to the public. There is need for local government administration to put in place a proactive measure for fiscal planning in order to ensure effective and efficient service delivery.

\section{Consideration for Future Study}

There is still room for future study because this research study covers only four (4) local governments out seven hundred and seventy four (774) local governments in Nigeria. It is therefore suggested that further researches should be carried out on the use of the concept of decentralization among tiers of government for service delivery.

\section{References}

Adamolekun, L. (1983). Public Administration: A Nigerian and comparative perspective. London: Longman.

Agrawal, A., \& Ribot, J.C. (1999). Accountability in decentralization: A framework with South Asian and West Africa cases. The Journal of Developing Areas, 33 (summer), 473-502.

Ajayi, K. (2002). Theory and Practice of Local Government. Ado Ekiti: UNAD.

Akindele, S.T., Olaopa, O.R., \& Obiyan, A.S. (2002). Fiscal federalism and local government finance in Nigeria: An examination of revenue rights and fiscal jurisdiction. International Review of Administrative Science, 68, (4), 557-577.

Awotokun, K. (2005). Local government administration under 1999 constitution in Nigeria. Journal of social science, 10, (2), 129-134.

Bahl, R., \& Linn, J. (1994). Fiscal decentralization and intergovernmental transfers in less developed countries. Publius, 24(1), 1-19.

Bardhan, P., \& Mookherjee, D. (2000c). "Capture and governance at local and national levels". American Economic Review, 90(2), 135-139.

Binswanger, H. (1999). Technical consultation on the decentralization of rural development, unpublished proceedings of development conference, Rome, 16-18, December 1997, Rome: Food and Agricultural Organization.

Boschmann, N. (2009) Fiscal decentralization and options for donor harmonization. Berlin: Development Partners Working Group on Local Governance and Decentralization, DPWG-LGD Paper.

Bird, R. M., \& Vaillancourt, F. (1995). Fiscal Decentralization in Developing Countries. The United Kingdom: University Press Cambridge.

Bird, R. M., Ebel, R. D., \& Wallich, C. (1995). Decentralization of the socialist state. Washington, DC USA: The World Bank. 


\section{Macrothink}

Journal of Public Administration and Governance ISSN 2161-7104 2012, Vol. 2, No. 4

Bennett, R. (1990). Decentralization, intergovernmental relations and markets: Towards a post-welfare agenda. Oxford: Clarendon Press.

Campbell, A., \& Coulson, A. (2006). Into the mainstream: Local democracy in central and eastern Europe. Local Government Studies, 32(5), 543-561.

Carrello, E. (1997). Local government and strategies for decentralization in the "state of the autonomies". Publius, 27(4), 39-63.

Dehn, Reinikka, \& Svensson (2003). "Survey tools for assessing performance in service delivery". In Bourguignon \& Pereira da Silva, eds. Evaluating the poverty and distributional impact of economic policies. Washington DC: Oxford University Press, and World Bank Research Group.

Elharaika, A.B (2007). Fiscal decentralization and public service delivery in South Africa. Economic Commission for Africa, African Trade Policy Centre, Working in Progress Paper, No. 58.

Federal Ministry of Finance, Abuja, Nigeria (2010). Distribution details of revenue allocation to local government councils by Federation Account Committee retrieved from the official website of Federal Ministry of Finance at http://www.fmf.com.

Lawal, S. (2000) "Local Government Administration in Nigeria: A practical approach". Ibadan: University Press Limited.

Manor, J (1999). The political economy of democratic decentralization. Washington DC: World Bank Development Research Group.

Manor, J., \& Richard, C. (1998). Democracy and Decentralization in South Asia and West Africa. Cambridge: Cambridge University Press.

Mass, A. (1959). The Press, New York, Ministry of Local Government and Information Circular Letter. Akure: February $18^{\text {th }}$ (1979).

Okafor, J. (2010). Local government financial autonomy in Nigeria: The state joint local government account. Commonwealth Journal of Local Governance, Issue 6, (July), 124-131.

Okeem, E. O. (1989). Education as instrument of social mobilization and rural development. Ibadan: A lead paper presented at the National Conference on Social Mobilization and Community Development.

Ola, R. F. (1984). Local Administration in Nigeria. London: Kegan Paul International.

Olowu, D. (2001). 'Pride and performance in African public services: Analysis of institutional breakdown and rebuilding efforts in Nigeria and Uganda'. International Review of Administrative Sciences, 67(1), 117-134.

Orewa, G., \& Adewunmi, J. B. (1983) Local government in Nigeria. Benin: The Changing Phase Benin: Ethiope Pub. Co.

Prudhomme, R. (1995). The dangers of decentralization. World Bank Research Observer, 
10(2), 201-220.

Reinikka, R. (2001). "Recovery in service delivery: Evidence from schools and health centers.” In Ritva Reininkka \& Paul Collier, eds. Uganda's recovery: The role of farms, firms, and government. World Bank Regional and sectoral studies. Washington DC: World Bank Development Research Group.

Reinikka, R., Svensson, J., \& Dehn, J. (2002). Survey tools for assessing performance in service delivery (World Bank regional and sectoral studies). Washington, DC: World Bank.

Ribot, J.C (1999). Decentralization, participation, and accountability in Sahel forestry: Legal instruments of political-administrative control. Africa, 69, (1), January, 23-65.

Ribot, J. C. (2002). African decentralization: Local actors, powers and accountability, UNRISD Programme on Democracy, Governance and Human Rights, Paper No. 8, December

Robertson, W. (1999). The role of participation and partnership in decentralized governance: A brief synthesis of policy lessons and recommendations of nine country case studies on service delivery for the poor. New York: The Human Development Report, UNDP.

Robinson, M. (2007). Introduction: Decentralizing service delivery? Evidence and policy implications. Institute of Development Studies, IDS Bulletin, 38 (1).

Saasa, O.S., Steffensen, J., Trollegaard, S., Mwanawina, I., \& Likulunga, M. (1999). Fiscal decentralization and Sub-national Government finance in relation to infrastructure and service provision in Zambia. New York: The World Bank.

Salihu, A. A., \& Khalil, S. (2011). Service delivery by local government in Nigeria: The delivery of primary education and healthcare service by local government in Nigeria. Germany: Lambert Academic Publishing.

Smoke, P. (1999). Understanding decentralization in Africa: An overview of key issues and challenges. Regional Development Dialogue, 20, (2), 1-17.

Smoke, P. (1999). 'Fiscal decentralization in developing countries: A review of current concepts and practice. Geneva: United Nations Research Institute for Social Development.

Tiebout, C. M. (1956). 'A pure theory of local expenditures'. The Journal of Political Economy, 64(1), 416-424.

Wibbels, E. (2004). Federalism and the market: Intergovernmental conflict and economic reform in the developing world. Cambridge, UK: Cambridge University Press. 